\title{
CEFR-oriented probe into pronunciation: Implications for language learners and teachers
}

\author{
İbrahim Halil Topal ${ }^{\mathrm{a}} *$ (iD \\ ${ }^{a}$ Gazi University, Ankara, Turkey
}

APA Citation:

Topal, İ.H. (2019). CEFR-oriented probe into pronunciation: Implications for language learners and teachers. Journal of Language and Linguistic Studies, 15(2), 420-436.

Submission Date:05/07/2018

Acceptance Date:07/01/2019

\begin{abstract}
Adopting an action-oriented approach, Common European Framework of Reference for Languages (henceforth CEFR) (Council of Europe, 2001) can be considered as a general framework for language learning, teaching, and assessment across Europe. With its descriptors of language skills across proficiency levels, CEFR can be utilized as a guideline for language learners, teachers and assessors. Bearing this in mind, this paper aims to delve into pronunciation from a CEFR-oriented perspective by (i) exploring the skills and competences required to be considered as proficient language users with specific reference to phonetics and phonology on part of language learners and (ii) describing the standards of teaching profession with regard to pronunciation and its instruction in the light of CEFR and the standards of EFL/ESL Teachers of Adults (TESOL, 2008) with direct implications for teacher education contexts. While doing this, this paper further aims to contribute to the literature of teacher education in terms of pronunciation pedagogy with considerable implications with reference to previous research through further discussion.
\end{abstract}

(C) 2019 JLLS and the Authors - Published by JLLS.

Keywords: teacher education; CEFR; professionalism; pronunciation; language proficiency

\section{Introduction}

Common European Framework of Reference for Languages: Learning, teaching, assessment (Council of Europe, 2001) is a common core of languages providing a basis for learning, teaching, and assessment processes across Europe. The skills and competences that language learners have to acquire to be able to use a language communicatively and "act effectively" (Council of Europe, 2001, p.1) are described within this framework. In addition, "it provides the means for educational administrators, course designers, teachers, teacher trainers, examining bodies, etc., to reflect on their current practice, with a view to situating and coordinating their efforts and to ensuring that they meet the real needs of the learners for whom they are responsible" (Council of Europe, 2001, p.1). Presenting descriptors for skill-based language use across proficiency levels, this framework can be utilized as a broad and practical guideline for language learners, teachers and assessors for a degree of varying linguistic, educational and institutional purposes.

Considering the fact that knowledge of the phonology of the target language is required by language teachers (Brown, 1992; Dalton \& Seidlhofer, 1994; Jenkins, 1998; Murphy, 1997; Ross, 1992;

\footnotetext{
* İbrahim Halil Topal. Tel.: +0-312-484-5165

E-mail address: ibrahimtopal@gazi.edu.tr
} 
Underhill, 1994), the focus of this paper is to examine thoroughly the issues related to phonetics and phonology with regard to language learning and teaching from a CEFR perspective. However, the areas that will be focused in this paper will be implicated for English language teacher education. It therefore aims to explain the skills and competences that language learners (here teachers) have to possess to be able to use the target language effectively across $\mathrm{C} 1$ and $\mathrm{C} 2$ proficiency levels (as language teachers are expected to be proficient users of the target language) (TESOL, 2008), what language teachers can do to teach pronunciation while citing references to previous studies conducted on these issues. In this regard, this paper can be utilized as a CEFR-oriented guideline for pronunciation learning and teaching since it intends to describe the issues related to those two educational processes along with critical review of the relevant literature on each issue with further discussion.

\section{A Reference for Language Learning}

Prior to the elaboration of the skills and competences that language learners need to possess, the description of language learning below by CEFR (Council of Europe, 2001) adopting an action-oriented approach needs to be considered.

Language use, embracing language learning, comprises the actions performed by persons who as individuals and as social agents develop a range of competences, both general and in particular communicative language competences. They draw on the competences at their disposal in various contexts under various conditions and under various constraints to engage in language activities involving language processes to produce and/or receive texts in relation to themes in specific domains, activating those strategies which seem most appropriate for carrying out the tasks to be accomplished. The monitoring of these actions by the participants leads to the reinforcement or modification of their competences (p.9).

From the comprehensive description made above, it can be argued that there are certain competences such as communicative language competence expected to be acquired by language learners. Initially expressed by Hymes (1972), communicative competence consists of several components including linguistic, sociolinguistic and pragmatic competences. However, linguistic competence - phonological competence in particular - will be concentrated on in this paper in regard to its purposes. According to CEFR (Council of Europe, 2001), phonological competence is one of the competences included in linguistic competence which is also a sub-component of communicative language competence. This component "...relates not only to the range and quality of knowledge (e.g. phonetic distinctions) ..." (p.13) and it can therefore be claimed that language learners need to possess phonological competence allowing them to use the phonology of the target language effectively. In relation to phonological competence, there are some other concepts that need to be considered such as phonological awareness, phonemic awareness and metaphonological awareness.

\subsection{Phonological, Phonemic and Metaphonological Awareness}

Yopp and Yopp (2009) define phonological awareness as “... sensitivity to the sound structure of a language. It demands the ability to turn one's attention to sounds in spoken language while temporarily shifting away from its meaning" (p.12). Since how speech is constructed or what it is made up of is not necessarily apparent to language learners as speech "... is a highly complex signal made up of coarticulated segments, with acoustic information for each segment (consonant or vowel) overlapping extensively with information from neighboring segments" (Mody, 2003, p.30), language learners thus need to be aware of the phonological rules that govern speech. In other words, phonological awareness 
help learners distinguish between syllables, words, onsets and rimes. With regard to Pike's typological classification of languages as stress-timed (stressed syllables are uttered at approximately regular intervals) and syllable-timed (each syllables takes roughly the same amount of time to be uttered) (Pike, 1945), typological differences between languages may require language learners to be aware of the phonological systems of the languages. It can therefore be argued that language learners need to be trained through contrastive analysis so that they can distinguish between the syllables and sounds of both native and target languages.

Phonemic awareness, on the other hand, although being a subset of phonological awareness, refers to the ability to attend, recognize and exploit the smallest units of sound (phonemes) that help language speakers to distinguish between units of meaning (morphemes). In other words, it is an awareness of the ways "in which words and syllables can be divided into smaller units" (Goswami \& Bryant, 1990, p. 2) or an awareness of the sound system of language allowing an individual to make judgments about, or manipulate sounds and syllables in words. However, phonological awareness, along with the fact that it encompasses phonemic awareness, refers to the ability to attend, recognize and exploit larger units of sound such as onsets, rimes and syllables. Having a direct correlation with students' ability to read as they get older, phonemic awareness builds a foundation for students to understand the rules of the English language which in turn allows each student to apply these skills and increase his or her oral reading fluency and understanding of the text (Snider, 1997). For this reason, raising language learners' phonemic awareness is salient for receptive skills (reading and listening) which consequently might influence the development of expressive speech and language (Carroll \& Snowling, 2004; Gillon, 2005; Webster \& Plante, 1992).

Defined by Wrembel (2011) as the "explicit knowledge of selected aspects of L2 phonetics and phonology, analytic awareness of the formal properties of the target language as contrasted with the learner's L1 as well as a considerable level of processing control" (p. 106), metaphonological awareness is an essential skill to develop good pronunciation competence (Couper, 2011; Wrembel, 2005). In a study conducted by Venkatagiri and Levis (2007), metaphonological awareness was found to be significant with regard to speech comprehension. In other words, there is a strong relationship between what learners know of English phonetics and their speech comprehensibility. It is a well-known fact that many people fail to achieve acceptable, easily intelligible pronunciation in a foreign language and this failure impacts on successful communication and therefore mastery of acceptable, flowing speech or conversation involves going beyond the articulatory mechanics of individual phonemes or even words (Henderson, 2015). For this reason, it can be argued that prolific results can be obtained when learners' awareness of segmental and suprasegmental features can be raised through metaphonological awareness (Doughty \& Williams, 1998).

It can thus be summarized here that language teachers (also as being language learners) are expected to develop phonological competence as part of linguistic competences embedded in communicative language competence, along with the fact that phonological, phonemic and metaphonological awareness of language learners/teachers should be raised for better and sound pronunciation - and communication consequently.

\subsection{General Phonetic Awareness and Skills}

To speak, language learners must be able to "articulate the utterance (phonetic skills)" (Council of Europe, 2001, p.90) and to listen, they must be able to "perceive the utterance (auditory phonetic skills" (Council of Europe, 2001, p.90), both of which involves phonological processes on part of language learners in terms of reception, articulation, production and interaction. In other words, both auditory 
reception and production require language learners to develop certain phonetic skills and awareness. General phonetic awareness and skills were described in CEFR as follows:

- $\quad$ an ability to distinguish and produce unfamiliar sounds and prosodic patterns;

- $\quad$ an ability to perceive and catenate unfamiliar sound sequences;

- $\quad$ an ability, as a listener, to resolve (i.e. divide into distinct and significant parts) a continuous stream of sound into a meaningful structured string of phonological elements;

- $\quad$ an understanding/mastery of the processes of sound perception and production applicable to new language learning. (p.107)

When the skills described above are examined, it can be observed that those skills are related to the segmental features of a language. It can therefore be inferred that developing phonetic awareness requires the acquisition of segmental features of a language. Considering the significance of segmentals in communication (Anderson-Hsieh, Johnson \& Koehler, 1992; Derwing, Munro \& Wiebe, 1998; Derwing \& Rossiter, 2002; Munro, Derwing \&Thomson, 2015; Saito, 2011), it can be suggested that language learners should receive formal training on segmental features of language and be phonetically competent so as to be regarded as proficient users of the target language.

\subsubsection{Phonological Competence}

Being one of the components of linguistic competences, phonologic competence enables language learners to utilize and manipulate the phonology of the target language effectively. According to CEFR (Council of Europe, 2001) phonological competence involves a knowledge of, and skill in the perception and production of:

(i) the sound-units (phonemes) of the language and their realization in particular contexts (allophones);

(ii) the phonetic features which distinguish phonemes (distinctive features, e.g. voicing, rounding, nasality, plosion);

(iii) the phonetic composition of words (syllable structure, the sequence of phonemes, word stress, word tones);

(iv) sentence phonetics (prosody)

(v) sentence stress and rhythm

(vi) intonation;

(vii) phonetic reduction

(viii) vowel reduction

(ix) strong and weak forms

(x) assimilation

(xi) elision. (pp.116-117)

"The formation of phonological competence plays a great role in the development of foreign communicative competence as it deals with the consecutive and purposeful formation of the pronunciation bases of each type of speech activity" (Homutava, 2016, p. 1676). From the description of phonological competence made above, it can be observed that it requires the knowledge of both segmental and suprasegmental features of language. It can thus be assumed that language learners are expected to be proficient segmentally and suprasegmentally to be regarded as phonologically competent. In other words, being phonologically competent means the ability to decipher the sound system of a language. At suprasegmental level, however, phonological competence refers to an EFL learner's degree 
of sensitivity to suprasegmental aspects of a language (i.e. stress, pitch, juncture and intonation) denoting an EFL learner's ability to recognize main stress in words, compound words, phrases, and sentences, rising intonation in yes-no questions and falling intonation in wh-questions and normal statements (Hişmanoğlu, 2012).

\subsection{Common Reference Levels: Qualitative Aspects of Spoken Language Use}

CEFR divides, on a global scale, language proficiency levels into three: basic, independent and proficient users. As this paper aims to address to language teachers and carry implications for teacher education in regard to the professional standards for teacher education (Seufert et al.2005) which will be discussed later in detail, descriptors related to proficient users (namely, $\mathrm{C} 1$ and $\mathrm{C} 2$ ) will be taken as a basis. According to the grid on pages 28-29 in CEFR, some of the qualitative aspects of spoken language use related to the purposes of this paper are as follows:

Table 1. Qualitative Aspects of Spoken Language Use

\begin{tabular}{|c|c|c|}
\hline & Fluency & Interaction \\
\hline $\mathrm{C} 2$ & $\begin{array}{l}\text { Can express him/herself spontaneously at length with } \\
\text { a natural colloquial flow, avoiding or backtracking } \\
\text { around any difficulty so smoothly that the } \\
\text { interlocutor is hardly aware of it. }\end{array}$ & $\begin{array}{l}\text { Can interact with ease and skill, picking up and using } \\
\text { non-verbal and intonational cues apparently } \\
\text { effortlessly. Can interweave his/her contribution into } \\
\text { the joint discourse with fully natural turn-taking, } \\
\text { referencing, allusion making, etc. }\end{array}$ \\
\hline
\end{tabular}

C1 Can express him/herself fluently and spontaneously, Can select a suitable phrase from a readily available almost effortlessly. Only a conceptually difficult range of discourse functions to preface his remarks in subject can hinder a natural, smooth flow of order to get or to keep the floor and to relate his/her language. own contributions skillfully to those of other speakers

(adapted from CEFR, Council of Europe, pp.28-29)

Two out of five qualitative aspects of spoken language use were considered to be related to phonetics and phonology - pronunciation more particularly. Fluency and interaction were therefore selected as the aspects of spoken language use believed to be correlated with pronunciation, comprehensibility and accentedness (Derwing \& Munro 1997). Numerous studies (Derwing et al., 2004; Kormos \& Denes, 2004; Rossiter, 2009; Valls-Ferrer, 2011) concluded that fluency was affected by pausing and speech rate. Speaking of pauses, or junctures, which are considered to be one of the elements of intonation, are suprasegmental phonemic cues, a means by which a listener can distinguish between two otherwise identical sequences of sounds that have different meanings (Nicolosi, Harryman \& Kresheck, 2004). Considering the fact that pauses or junctures are salient in terms of continuous speech and intelligibility (Brown, 2014; Cutler \& Butterfield, 1992; Paterno, 2003), it can be asserted that language learners should receive professional training on intonation so as to manage to be fluent in the target language they are going to learn as required by $\mathrm{C} 1 / \mathrm{C} 2$ proficiency levels.

Interaction, which is another aspect of spoken language use, involves the utilization of intonation cues on part of language users. Defined by Wells (2006) as the melody of speech along with its inclusion of the study of rhythm of speech and how the interplay of accented, stressed, and unstressed syllables function as a framework onto which the intonation patterns are attached, intonation is considered to be made up of primary stress, pitch and juncture phonemes (Demirezen, 2008). Taking into consideration the significance of primary stress (Harmer, 2001; Jenkins, 2002) pitch phonemes (Maastricht, Krahmer \& Swerts, 2016; Roach, 2001; Spaai \& Hermes, 1992; Wells, 2006) and juncture phonemes (Brown, 
2014; Cutler \& Butterfield, 1992; Pickering, 2002; Paterno, 2003), it is plausible to assert that teaching intonation to language learners is of urgent need to be regarded as proficient users of language as expressed in CEFR. According to the descriptors of interaction for C1-C2 levels in spoken language use, it is expected of language learners to be able to use intonation cues to convey the intended meaning and sound communication.

It can be summarized that language learners need to be equipped with both segmental and suprasegmental knowledge to be fluent in interactions and thus considered proficient users of language (C1-C2). Being fluent and using intonation cues effortlessly are two of the skills language users need to possess; however, it is expected of language teachers to possess these skills as well as be knowledgeable enough to teach the phonological rules that help their learners to be fluent and utilize intonation cues in spoken interaction. For this, segmental and suprasegmental instruction can be embedded into the English language teacher education curriculum.

\subsection{The Context of Language Use: Conditions and Constraints}

Before elaborating on the conditions for language use, it must be ascertained that language use varies greatly according to the context it is used in. With regard to teacher education, it can be claimed that occupational and educational domains are two of the four domains where language is mostly used. As in other domains, various constraints are imposed on language users by external conditions under which communication occurs. "The ability of all speakers, especially learners, to put their language competence into action depends greatly on the physical conditions under which communication takes place" (Council of Europe, 2001, p.47). Clarity of pronunciation, being one of the physical conditions, affects language use and understandability. According to Levis and Grant (2003), word clarity covers the difficulties encountered by language users in uttering words so that listeners can understand them. They maintain that these difficulties include "consonant and vowel sounds, the lengthening of stressed vowels, stress patterns in multisyllabic words, and the pronunciation of lexical units, such as on the other hand or to sum up" (p.15).

With regard to clarity of pronunciation, two issues can be raised here. Pronunciation can be categorized as segmentals and suprasegmentals, with the first one functioning at phoneme-level while the second at beyond phonemes. It can thus be assumed that clear pronunciation consists of being proficient in both segmental and suprasegmental/prosodic features (Pennington \& Richards, 1986) since lack of either of them leads to problems with intelligibility (Avery \& Ehrlich, 1992; Derwing \& Rossiter, 2003; Hahn, 2004; Morley, 1991). Clear pronunciation is impacted by a number of factors as well. According to International Communication Centre of Carnegie Mellon University, several factors including age, native language (similarities and differences between the target language), length of time using English (risk of fossilized pronunciation errors due to lack of feedback), social pressure (conscious or unconscious from immediate vicinity for not sounding like native-speaker) and innate ability (recognition and production of subtle differences in sounds) are the predictors of clear pronunciation. However, clear pronunciation can be achieved by language users (Dauer, 2005; Murphy, 2013; Scarcella \& Oxford, 1994). With this in mind, language learners are expected to possess a good command of pronunciation of the target language.

Another determinant that seems to influence communication and is categorized under paralinguistics in CEFR (Council of Europe, 2001) is prosodic qualities - qualities which can be considered as "paralinguistic if they carry conventionalized meanings (e.g. related to attitudes and states of mind) but fall outside the regular phonological system in which prosodic features of length, tone, stress may play a part" (p.89) through voice quality, pitch, loudness and length. While prosodic qualities are at issue here, the functions of intonation (one of the elements of prosody) are worth mentioning. Several scholars (Crystal, 1995; Halliday, 1967, 1970, 1994; Roach, 1991; Wells, 2006) came up with different functions 
of intonation including attitudinal, grammatical, informational, discourse, psychological and indexical. Without focusing on each of these functions, it needs to be made clear that lack of intonation or prosodic qualities may result in foreign accent and unnatural speech (Collins \& Mees, 2013; Brown, 2014; Götz, 2013; Zsiga, 2013).

It can thus be concluded here that clarity of pronunciation and prosodic qualities are two of the conditions that may constrain language use and are therefore salient in communication. Despite the factors affecting those conditions, it is expected of language learners to pay attention to these and utilize them in their speech for better and sound communication.

\title{
3. A Reference for Language Teaching
}

CEFR can be utilized as a guideline for language teachers as well since it proposes a general framework to be employed as an approach to language teaching across skills and proficiency levels. In this part, qualities and standards of language teachers and pronunciation development in language learners will be presented.

\subsection{Standards for Language Teachers}

CEFR maintains that it should be realized by teachers that "their actions, reflecting their attitudes and abilities, are a most important part of the environment for language learning/acquisition. They present role-models which students may follow in their future use of the language and their practice as future teachers" (Council of Europe, 2001, p.144). It must be emphasized here that as role-models, language teachers should possess certain standards to be able to teach. According to the Standards for ESL/EFL Teachers of Adults (TESOL, 2008, p.86), there are eight domains where language teachers need to possess certain standards. However, only the relevant standards to the purposes of this paper are presented in the following table.

Table 2. Standards for EFL/ESL Teachers of Adults by TESOL

\begin{abstract}
Domain: Language Proficiency
Standard 5: Teachers demonstrate proficiency in social, business/workplace and academic English. Proficiency in speaking, listening, reading and writing means that a teacher is functionally equivalent to a native speaker with some higher education.

\section{Domain: Commitment and Professionalism}

Standard 8: Teachers continue to grow in their understanding of the relationship of second language teaching and learning to the community of English language teaching professionals, the broader teaching community, and communities at large, and use these understandings to inform and change themselves and these communities.
\end{abstract}

(TESOL, 2008, p.86)

Since language teachers present role-models for their students, they are expected to possess a good command of phonetics and phonology in regard to language proficiency mentioned in Standard 5. "...A teacher is functionally equivalent to a native speaker with some higher education" (TESOL, 2008, p.86) implies that language teachers are required to have clear and natural pronunciation as well as phonetic, phonological, and metaphonological competence and awareness to be able to draw on their knowledge and pass this on their students. As Standard 5 implies, C1 and C2 proficiency levels in CEFR can be considered as the standard for language teachers to possess along with their descriptors.

With regard to commitment and professionalism, there are two issues to be considered for both preservice and in-service language teachers. First, formal training on pronunciation should be integrated into the curriculum with some practical and remediating insights into teacher education. Second, both 
pre-service and in-service language teachers should possess and develop phonetic, phonological, and metaphonological competence and awareness. As Elliott (1991, p.310) put forward, any model of professional education/training should contain conceptualizations of (1) professional competence, (2) professional knowledge, and (3) curriculum and pedagogy. Bearing all this in mind, it can be argued that language teachers are expected to possess a good command of the target language as part of teaching standards, professional competence and professional knowledge.

\subsection{The Nature of Pronunciation Instruction}

CEFR offers some strategies and techniques for teaching pronunciation or methods for learners to develop their ability to pronounce a language as follows:

(i) simply by exposure to authentic spoken utterances;

(ii) by chorused imitation of the teacher; audio-recorded native speakers; videorecorded native speakers;

(iii) by individualized language laboratory work;

(iv) by reading aloud phonetically weighted textual material;

(v) by ear-training and phonetic drilling;

(vi) as iv) and v) but with the use of phonetically transcribed texts;

(vii) by explicit phonetic training;

(viii)by learning orthoepic conventions (i.e. how to pronounce written forms);

(ix) by some combination of the above (p.153)

The utilization of authentic materials is very significant in pronunciation teaching (Celce-Murcia et al., 2010; Elliott, 1997; Jones, 1997; Morley, 1991; Jones \& Evans, 1995; Wells, 2006) as in other skills and areas of a language. Regarding the imitation of the teacher, Celce-Murcia, Brinton and Goodwin (2010) propose Intuitive-Imitative Approach which "depends on the learner's ability to listen to and imitate the rhythms and sounds of the target language without the intervention of any explicit information" (p.2). However, it must be stated here that learning pronunciation through imitation of teachers is very old-fashioned method that dated back to the 1940s and 1960s (Morley, 1991) and therefore teaching pronunciation should be contextualized (Celce-Murcia \& Goodwin, 1991; Morley, 1991; Topal, 2017). The use of language laboratory, on the other hand, was harshly criticized as cited in Navas-Brenes (2006) as it failed to implement appropriate activities and teachers' confusion about its role in language classroom. Additionally, reading aloud was also criticized because of controlled and slightly unnatural texts (Celce-Murcia et al., 1996). Regarding phonetic drilling, Ducca (2016) expressed that it was effective for the pronunciation of $/ \mathrm{s} /, \mathrm{J} /$, and $/ \mathrm{t} \mathrm{f} /$ in isolated phonemes and words, no improvement was observed during actual conversations. In a similar vein, several other scholars reported the effectiveness of phonetic drills in terms of teaching or practicing segmental features (Demirezen, 2005, 2006, 2007, 2008; Hişmanoğlu, 2007). However, the same may not be stated for the teaching of suprasegmentals such as intonation as it must be taught in context and discourse (Brazil, Coulthard, \& Johns, 1980; Clennell, 1997; Thompson, 1995). It was revealed in several studies (Bradlow, 2008; Loebach \& Pisoni, 2008; Pisoni, Lively \& Logan, 1994; Vallabha \& McClelland, 2007) that explicit phonetic training enabled phonetic learning with focused attention on the stimulus differences, explicit category labels, and performance feedback.

No matter what techniques or methods are employed for the teaching of pronunciation, it must be borne in mind that teaching methodologies depend on the local, personal, educational and institutional objectives and thus all of the ways of teaching pronunciation mentioned in CEFR (Council of Europe, 2001) can be utilized according to the purposes of instruction. Also, a distinction must be made between 
teaching pronunciation in second or foreign language educational settings and teacher education settings. This issue will be discussed in the upcoming part.

\subsection{Pronunciation Teaching in EFL/ESL and Teacher Education Settings}

This distinction of pronunciation learning/teaching between EFL/ESL and teacher education settings was made by several scholars (Celce-Murcia et al., 1996; Burgess \& Spencer, 2000; Dalton \& Seidlhofer, 1994; Underhill, 1994). As a matter of fact, this distinction is very important since they are different contexts; therefore, they may both specify varying objectives. For instance, the teaching of segmental and suprasegmental features of a language may be crucial for one context while it may not have the same degree of importance in the other. While methodology practice and knowledge of the phonology of the target language can be vital in the training and education of language teachers (Brown, 1992; Burgess \& Spencer, 2000; Dalton \& Seidlhofer, 1994; Murphy, 1997), learning how to pronounce the sounds of the target language rather than to learn to any great extent about those sounds may prevail for language users in second or foreign language education settings (Burgess \& Spencer, 2000). With this in mind, the following outline can be utilized in the distinction of these two contexts towards pronunciation teaching.

Table 3 .The relationships between pronunciation-teaching and phonology in SFLT and TELT

\begin{tabular}{cc}
\hline $\begin{array}{c}\text { SFLT } \\
\text { Teaching Pronunciation }\end{array}$ & $\begin{array}{c}\text { TELT } \\
\text { Pronunciation-teaching } \\
\text { methodology \& phonology }\end{array}$ \\
\hline Selection of phonological features to be practiced \\
$\begin{array}{c}\uparrow \\
\text { Ordering of phonological features to be practiced }\end{array}$ & $\begin{array}{c}\text { Selection of phonological features to be studied } \\
\uparrow\end{array}$ \\
Ordering of phonological features to be studied
\end{tabular}

Integration of pronunciation practice in multipurpose, broadly communicative language learning framework

\section{$\uparrow$}

Selection of appropriate discourse

Degree of overtness concerning pronunciation practice

Pronunciation-teaching methodology strategy \& tactics

$\uparrow$

Degree of phonological explicitness

\author{
Integration of pronunciation-teaching methodology \\ $\&$ phonology-study \\ $\uparrow$ \\ Selection of appropriate priorities \& strategy
}

\author{
Phonology-teaching methodology \\ strategy \& tactics \\ $\uparrow$ \\ Degree of phonological detail
}

(Burgess \& Spencer, 2000, p. 194)

Regarding pronunciation teaching in EFL/ESL and teacher education contexts, a number of issued need to be considered. From a CEFR perspective, it can be stated that the content and the degree to which pronunciation is taught may change and depend on the objectives in EFL and ESL contexts. Also, this can be employed across all proficiency levels. However, the same cannot be stated for teacher education settings since teachers present role-models for their students and therefore need to possess a good command of phonetics and phonology of the target language. Alongside with that, teachers should develop phonological, phonetic and metaphonological awareness and be equipped with the knowledge of the phonology of the target language as the standards of teaching require (TESOL, 2008). Apart from this, as language teachers, they are expected to possess a good command of the phonetics and phonology of the target language as well as be knowledgeable and competent enough to teach this to their students. In other words, language teachers need to learn the methodology and pedagogy of phonetics and 
phonology instruction in addition to language proficiency - more specifically the skills and knowledge of pronunciation.

\section{Discussion}

This paper delves into the integration of pronunciation in CEFR (Council of Europe, 2001) on part of language learners and teachers. Being one of the crucial aspects of language (Baker, 2014; CelceMurcia et al., 2010; Foote, Holtby \& Derwing, 2012; Jenkins, 2000; Levis, 1999; Munro \& Derwing, 2011; Reed \& Levis, 2015; Saito, 2011; Underhill, 2005) pronunciation has been ignored or paid less attention in teacher education context (Demirezen \& Kulaksiz 2015; Gilakjani, 2016; Levis, 2005; Szpyra, 2014; Wei, 2006). From a CEFR-oriented perspective, both language learners and teachers have some responsibilities in relation to pronunciation.

For language learners, it can be argued that they need to fulfil the requirements of competent language users through several skills and awareness including phonological, phonemic and metaphonological awareness as well as phonological competence as part of communicative language competence and linguistic competence - all of which requires them to possess a good knowledge of segmental and suprasegmental features of the target language. Another issue that correlates with pronunciation is the acquisition of fluency and interactional skills in spoken language on part of language users. Considering the relationship of fluency with comprehensibility and accentedness (Derwing \& Munro 1997) alongside of the elements of intonation such as juncture (Derwing et al., 2004; Ferrer, 2011; Kormos \& Denes, 2004; Rossiter, 2009), it can be claimed that language learners need to be fluent in spoken interactions so as to be considered proficient and competent language users. One last issue with language users is the physical conditions - clarity of pronunciation and prosodic qualities (Council of Europe, 2001, p.89) that might constrain language use. In other words, it can be expressed that clear pronunciation along with the inclusion of prosodic qualities (i.e. pitch, loudness, length) may have a negative impact on spoken language and therefore special significance should be attached to these components during spoken interactions.

Language teachers, on the other hand, need to possess all the skills and competences mentioned above since they are also language learners and users. In addition, they have some other responsibilities assigned to them by teaching profession. According to the Standards of ESL/ELF Teachers of Adults (TESOL, 2008), language teachers need to achieve certain standards (hereby language proficiency and commitment and professionalism). Since they "present role-models which students may follow in their future use of the language and their practice as future teachers" (Council of Europe, 2001, p.144), they are required to retain high level language proficiency to be regarded as competent and proficient language users. Additionally, they should be equipped with certain phonological skills and competences and possess the knowledge of phonology in order to be able to represent the language they teach as part of commitment and professionalism. Apart from this, language teachers need to be knowledgeable about the methodology since the teaching of phonetics and phonology (segmental and suprasegmental features of the language) necessitates a different pedagogy than in ESL/EFL context (Burgess \& Spencer, 2000). Aside from the fact that language teachers need to be competent and proficient in the target language, the instruction of phonetics and phonology - more specifically, segmentals and suprasegmentals should be incorporated into the curricula of teacher education (Burgess \& Spencer, 2000; Derwing \& Munro, 2005; MacDonald, 2002; McGregor, 2018). Another issue on part of language teachers is the nature of pronunciation instruction. As proposed by CEFR (Council of Europe, 2001, p.153), there can be a number of ways of teaching pronunciation. It must be reminded here that the way pronunciation is taught is context and objective-dependent. However, several studies suggest and promote the teaching 
of pronunciation in communicative context (Baker, 2014; Baker \& Murphy, 2011; Celce-Murcia et al., 2010; Hişmanoğlu \& Hişmanoğlu, 2010; Levis, 2005; Morley, 1991). Considering the fact that nonnative speakers of English are in need of special treatment in terms of pronunciation (Baker \& Murphy, 2011; Çakır \& Baytar, 2014; Darcy, 2018; Demirezen, 2010; Derwing \& Munro, 2005; Fraser, 1999; Levis, 2005), it can be suggested that they should receive explicit and systematic pronunciation training.

\section{Conclusions}

This paper intended to explore into pronunciation from a CEFR-oriented perspective for language learners and teachers. All relevant parts in CEFR (Council of Europe, 2001) in relation to pronunciation were illustrated and discussed with reference to previous research conducted on each issue mentioned in this paper. It was discussed in this paper that language learners/teachers need to acquire certain skills and competences to be regarded as competent and proficient language users. It was also expressed that language teachers need to possess certain standards (i.e. language proficiency, commitment and professionalism) to be qualified as teachers with reference to the standards of EFL/ESL Teachers of Adults (TESOL, 2008) in addition to the skills and competences (i.e. phonological competence, phonetic awareness, etc.) required to be regarded as proficient language users as part of linguistic competence mentioned in CEFR (Council of Europe, 2001). It was further discussed that there should be a distinction made between pronunciation instruction in ESL/EFL and teacher education contexts since both involve varying requirements on part of learners and teachers. It can be concluded that language teachers - also as language learners - need to be endowed with phonetic and phonological skills, awareness and competences to be considered as proficient language users along with the fact that they present rolemodels for their students; be fluent in spoken interactions bearing in mind the significance of pronunciation in fluency and interaction (Derwing \& Munro 1997; Derwing et al., 2006, 2007; Murphy, 1991; Rossiter, 2009); be aware of certain physical conditions (i.e. clarity of pronunciation and prosodic qualities) that might impact or constrain language use; achieve the standards of teaching profession thus have a good command of the target language - especially knowledge of phonology - with regard to commitment and professionalism (TESOL, 2008).

\section{References}

Anderson-Hsieh, J., Johnson, R., \& Koehler, K. (1992). The relationship native speaker judgments of nonnative pronunciation and deviance prosody, and syllable structure. Language Learning, 42(4), 529-555.

Baker, A. (2014). Exploring teachers' knowledge of second language pronunciation techniques: teacher cognitions, observed classroom practices, and student perceptions. TESOL Quarterly, 48(1), 136-163.

Baker, A., \& Murphy, J. (2011). Knowledge base of pronunciation teaching: staking out the territory. TESL Canada Journal, 28(2), 29-50.

Bradlow, A. R. (2008). Training non-native language sound patterns: lessons from training Japanese adults on the English. Phonology of Second Language Acquisition, 36, 287-308.

Brazil, D., Coulthard, M., Johns, C.(1980). Discourse intonation and language teaching. London: Longman. 
Brown, A. (2014). Pronunciation and phonetics: A practical guide for English language teachers. New York: Routledge.

Brown, A. (1992). Twenty questions. In: Brown, A. (Ed.), Approaches to Pronunciation Teaching. Review of English Language Teaching, 2(2). Macmillan, London, pp. 1-17.

Burgess, J., \& Spencer, S. (2000). Phonology and pronunciation in integrated language teaching and teacher education. System, 28(2), 191-215.

Çakır, İ., \& Baytar, B. (2014). Foreign language learners' views on the importance of learning the target language pronunciation. Journal of Language and Linguistic Studies, 10(1), 99-110.

Carrol, J. M., \& Snowling, M. J. (2004). Language and phonological skills in children at high risk of reading difficulties. Journal of Child Psychology and Psychiatry, 45, 631-640.

Celce-Murcia, M., \& Goodwin, J. (1991). Teaching pronunciation. In M. Celce-Murcia (Ed.), Teaching English as a second or foreign language (2nd ed., pp. 136-153). New York, NY: Newbury House.

Celce-Murcia, M., Brinton, D.M., Goodwin, J.M. (1996). Teaching Pronunciation: A Reference for Teachers of English to Speakers of Other Languages. Cambridge University Press, Cambridge.

Celce-Murcia, M., Brinton, D. M., \& Goodwin, J. M. (2010). Teaching pronunciation hardback with audio CDs (2): A course book and reference guide. Cambridge: Cambridge University.

Clennell, C. (1997). Raising the pedagogic status of discourse intonation teaching. ELT Journal, 51(2), $117-125$.

Collins, B., \& Mees, I. M. (2013). Practical phonetics and phonology: a resource book for students. New York: Routledge.

Council of Europe. (2001). Common European framework of reference for languages: Learning, teaching, assessment. Cambridge, U.K: Press Syndicate of the University of Cambridge.

Couper, G. (2011). What makes pronunciation teaching work? Testing for the effect of two variables: socially constructed metalanguage and critical listening. Language Awareness, 20, 159-182.

Crystal, D. (1995). The Cambridge encyclopedia of the English language. Cambridge: Cambridge University.

Cutler, A., \& Butterfield, S. (1992). Rhythmic cues to speech segmentation: Evidence from juncture misperception. Journal of Memory and Language, 31(2), 218-236.

Dalton, C., Seidlhofer, B., (1994). Pronunciation. Oxford University Press, Oxford.

Darcy, I. (2018). Powerful and Effective Pronunciation Instruction: How Can We Achieve It? CATESOL Journal, 30(1), 13-45.

Dauer, R. M. (2005). The lingua franca core: A new model for pronunciation instruction? TESOL Quarterly, 39(3), 543-550.

Demirezen, M. (2005). Rehabilitating a fossilized pronunciation error: the/v/and/w/contrast by using the audio-articulation method in teacher training in Turkey. Journal of Language and Linguistic Studies, 1(2). 183- 191.

Demirezen, M. (2006). Flapping in North American pronunciation: Case 1 'The change of $/ \mathrm{t} / \mathrm{and} / \mathrm{d} /$ into [D] in pronunciation'. Journal of Language and Linguistic Studies, 2(1). 88-100. 
Demirezen, M. (2007). A model to rehabilitate a fossilized pronunciation error of Turkish English language teachers: The English consonant phoneme $/ \mathrm{y} /$ wrongly articulated as $/ \mathrm{yk} /$ through nasal devoicing. Journal of Language and Linguistic Studies, 3(2). 290-303.

Demirezen, M. (2008). The recognition and the production of question forms of English intonation by Turkish first year students. Worldwide Forum on Education and Culture-Putting Theory into Practice: Teaching for the Next Century .4-5 December, Rome, Italy.

Demirezen, M. (2010). The causes of the schwa phoneme as a fossilized pronunciation problem for Turks. Procedia-Social and Behavioral Sciences, 2(2), 1567-1571.

Demirezen, M., \& Kulaksiz, E. (2015). Correct pronunciation as work ethics in teacher education. Procedia-Social and Behavioral Sciences, 199, 713-721.

Derwing, T. M., \& Munro, M. J. (1997). Accent, intelligibility, and comprehensibility. Studies in second language acquisition, 19(01), 1-16.

Derwing, T. M., \& Rossiter, M. J. (2002). ESL learners' perceptions of their pronunciation needs and strategies. System, 30(2), 155-166.

Derwing, T. M., \& Rossiter, M. J. (2003). The effects of pronunciation instruction on the accuracy, fluency, and complexity of L2 accented speech. Applied Language Learning, 13(1), 1-17.

Derwing, T. M., Munro, M. J., \& Thomson, R. I. (2007). A longitudinal study of ESL learners' fluency and comprehensibility development. Applied Linguistics, 29(3), 359-380.

Derwing, T. M., Munro, M. J., \& Wiebe, G. (1998). Evidence in favor of a broad framework for pronunciation instruction. Language learning, 48(3), 393-410.

Derwing, T. M., Rossiter, M. J., Munro, M. J., \& Thomson, R. I. (2004). Second language fluency: Judgments on different tasks. Language learning, 54(4), 655-679.

Derwing, T. M., Thomson, R. I., \& Munro, M. J. (2006). English pronunciation and fluency development in Mandarin and Slavic speakers. System, 34(2), 183-193.

Doughty, C., Williams, J. (1998). Focus on Form in Classroom Second Language Acquisition. Cambridge: Cambridge University Press.

Ducca, J. A. D. (2016). Report of learning experiences in didactical conditions for teaching grammar, vocabulary, and pronunciation to Katty, a student with dyslexia. Actualidades Investigativas en Educación, 16(2), 13.

Elliott, A. R. (1997). On the teaching and acquisition of pronunciation within a communicative approach. Hispania,8(1), 95-108.

Elliott, J. (1991). A model of professionalism and its implications for teacher education. British Educational Research Journal, 17(4), 309-318.

Foote, J. A., Holtby, A. K., \& Derwing, T. M. (2012). Survey of the teaching of pronunciation in adult ESL programs in Canada, 2010. TESL Canada journal, 29(1), 1-22.

Fraser, H., \& Perth, H. F. (1999). ESL pronunciation teaching: Could it be more effective. Australian Language Matters, 7(4), 7-8.

Gilakjani, A. P., \& Sabouri, N. B. (2016). Why Is English Pronunciation Ignored by EFL Teachers in Their Classes? International Journal of English Linguistics, 6(6), 195. 
Gillon, G. T. (2005). Facilitating phoneme awareness development in 3-and 4-year-old children with speech impairment. Language, Speech, and Hearing Services in Schools, 36(4), 308-324.

Goswami, U., \& Bryant, P. E. (1990). Phonological Skills and Learning to Read. Hove, East Sussex: Psychology Press.

Götz, S. (2013). Fluency in native and nonnative English speech (Vol. 53). Philadelphia, PA: John Benjamins.

Hahn, L. D. (2004). Primary stress and intelligibility: Research to motivate the teaching of suprasegmentals. TESOL Quarterly, 38(2), 201-223

Halliday, M. A. K. (1967). Intonation and grammar in British English. The Hague: Mouton.

Halliday, M. A. K. (1970). A course in spoken English: Intonation. London: Oxford.

Halliday, M. A. K. (1994). Functional grammar. London: Edward Arnold.

Harmer, J. (2001). The practice of English language teaching (3rd ed.). Harlow, England: Pearson.

Henderson, A. (2015). Review of Pronunciation in EFL instruction: A Research-Based Approach, by Jolanta Szpyra-Kozłowska, Multilingual Matters. Retrieved from http://hal.univ-smb.fr/hal01644690/document.

Hişmanoğlu, M. (2007). The [0:] and [ov] contrast as a fossilized pronunciation error of Turkish learners of English and solutions to the problem. Journal of Language and Linguistic Studies, 3(1). 99-115.

Hişmanoğlu, M. (2012). Teaching word stress to Turkish EFL (English as a Foreign Language) learners through internet-based video lessons. US-China Education Review, A1, 26-40.

Hişmanoğlu, M., \& Hişmanoğlu, S. (2010). English language teachers 'perceptions of educational supervision in relation to their professional development: A case study of Northern Cyprus. Novitas-ROYAL (Research on Youth and Language), 4(1), 16-34.

Homutava, A. (2016). Phonological Competence: A System of Exercises. 10th International Technology, Education and Development Conference, Valencia, Spain, 7-9 March (pp. 16761683).

Hymes, D. (1972). “On communicative competence”. In: J.B. Pride and J. Holmes (Eds.) Sociolinguistics. Selected Readings. Harmondsworth: Penguin, (pp. 269-293).

Jenkins, J. (2000). The phonology of English as an international language. Oxford: Oxford University Press.

Jenkins, J. (2002). A sociolinguistically based, empirically researched pronunciation syllabus for English as an international language. Applied linguistics, 23(1), 83-103.

Jenkins, J. (1998). Which pronunciation norms and models for English as an International Language? ELT Journal, 52(2), 119-126.

Jones, R. H. (1997). Beyond "listen and repeat": Pronunciation teaching materials and theories of second language acquisition. System, 25(1), 103-112.

Jones, R. H., \& Evans, S. (1995). Teaching pronunciation through voice quality. ELT Journal, 49(3), 244-251.

Kormos, J., \& Dénes, M. (2004). Exploring measures and perceptions of fluency in the speech of second language learners. System, 32(2), 145-164. 
Levis, J. M. (1999). Intonation in theory and practice, revisited. TESOL Quarterly, 33(1), 37-63.

Levis, J. M. (2005). Changing contexts and shifting paradigms in pronunciation teaching. TESOL Quarterly, 39(3), 369-377.

Levis, J. M., \& Grant, L. (2003). Integrating pronunciation into ESL/EFL classrooms. TESOL Journal, 12(2), 13-19.

Loebach, J. L., \& Pisoni, D. B. (2008). Perceptual learning of spectrally degraded speech and environmental sounds. The Journal of the Acoustical Society of America, 123(2), 1126-1139.

Maastricht, L., Krahmer, E., \& Swerts, M. (2016). Prominence patterns in a second language: Intonational transfer from Dutch to Spanish and vice versa. Language Learning, 66(1), 124-158.

MacDonald, S. (2002). Pronunciation-views and practices of reluctant teachers. Prospect, 17(3), 3-18.

McGregor, A., \& Reed, M. (2018). Integrating Pronunciation into the English Language Curriculum: A Framework for Teachers. CATESOL Journal, 30(1), 69-94.

Mody, M. (2003). Phonological basis in reading disability: A review and analysis of the evidence. Reading and Writing: An interdisciplinary Journal, 16, 21-39.

Morley, J. (1991). The pronunciation component in teaching English to speakers of other languages. TESOL Quarterly, 25(3), 481-520.

Munro, M. J., \& Derwing, T. M. (2011). The foundations of accent and intelligibility in pronunciation research. Language Teaching, 44(3), 316-327.

Munro, M. J., Derwing, T. M., \& Thomson, R. I. (2015). Setting segmental priorities for English learners: Evidence from a longitudinal study. International Review of Applied Linguistics in Language Teaching, 53(1), 39-60.

Murphy, J. (2013). Teaching pronunciation. Alexandria, VA.: TESOL.

Murphy, J.M., (1997). Phonology courses offered by MATESOL programs in the U.S. TESOL Quarterly, 31(4), 741-764.

Navas-Brenes, C. A. (2006). The language laboratory and the EFL course. Revista Electrónica Actualidades Investigativas en Educación, 6(2), 1-25.

Nicolosi, L., Harryman, E., Kresheck, J. (2004). Juncture. Terminology of Communication Disorders: Speech-Language-Hearing (5th ed.). Philadelphia, PA: Lippincott Williams \& Wilkins.

Paterno, A. (2003). Handbook for oral readers of English as a second language. Philippine: Rex Book Store.

Pennington, M. C., \& Richards, J. C. (1986). Pronunciation revisited. TESOL Quarterly, 20(2), 207225.

Pickering, L. (2002). Patterns of intonation in cross-cultural communication exchange structure in NSTA ITA classroom discourse. Proceeding of the Seventh Annual Conference on Language Interaction and Culture, University of California, Santa Barbara, 4, 1-17.

Pike, K.L. (1945). "The intonation of American English". In Bolinger, D. (ed.): Intonation. Harmondsworth: Penguin: 53-83.

Pisoni, D. B., Lively, S. E., \& Logan, J. S. (1994). Perceptual learning of nonnative speech contrasts: Implications for theories of speech perception. In J. C. Goodman \& H. C. Nusbaum (Eds.), The 
development of speech perception: The transition from speech sounds to spoken words (pp. 121166). Cambridge, MA, US: The MIT Press.

Reed, M., \& Levis, J. (2015). The handbook of English pronunciation. Oxford: Wiley-Blackwell.

Roach, P. (1991) English phonetics and phonology. A practical course. (2nd ed.) Cambridge: Cambridge. Roach, P. (2001). Phonetics. Oxford: Oxford.

Ross, L. 1992. Teaching Phonology to teachers: the phonology element in initial training courses. In: Brown, A. (Ed.), Approaches to Pronunciation Teaching. Review of English Language Teaching, 2(2), 18-28.

Rossiter, M. J. (2009). Perceptions of L2 fluency by native and non-native speakers of English. Canadian Modern Language Review, 65(3), 395-412.

Saito, K. (2011). Examining the role of explicit phonetic instruction in native-like and comprehensible pronunciation development: An instructed SLA approach to L2 phonology. Language awareness, 20(1), 45-59.

Scarcella, R. C., \& Oxford, R. L. (1994). Second language pronunciation: State of the art in instruction. System, 22(2), 221-230.

Seufert, P., Sherman, R., Amador, N., Condelli, L., Silver- Pacuilla, H., Tetteyfio, S., Faller, B., Knight, L., \& Ward, K. (2005). A process guide for establishing state adult education content standards. Washington, DC: American Institutes for Research.

Snider, V. E. (1997). The relationship between phonemic awareness and later reading achievement. The Journal of Educational Research, 90(4), 203-211.

Spaai, W., \& D. Hermes (1992). A Visual Display for the Teaching of Intonation. CALICO Journal, 10(3), 19-30.

Szpyra-Kozłowska, J. (2014). Pronunciation in EFL Instruction: A Research-Based Approach. Bristol, UK: Multilingual Matters.

TESOL (2008). Standards for ESL/EFL Teachers of Adults. Alexandria, VA: TESOL Press.

Thompson, S. (1995). Teaching intonation on questions. ELT Journal, 49(3), 235- 243.

Topal, İ. H. (2017). An Analysis of the Intonation Patterns of If-Clauses in Turkish English Majors (Master's thesis), Hacettepe University, Institute of Educational Sciences, Ankara.

Underhill, A. (2005). Sound Foundations: Learning and Teaching Intonation, (2nd Ed.). Oxford: Macmillan.

Underhill, A., (1994). Sound Foundations. Heinemann, London.

Vallabha, G. K., \& McClelland, J. L. (2007). Success and failure of new speech category learning in adulthood: Consequences of learned Hebbian attractors in topographic maps. Cognitive, Affective, \& Behavioral Neuroscience, 7(1), 53-73.

Valls-Ferrer, M. (2011). The development of oral fluency and rhythm during a study abroad period. Doctoral dissertation. Universitat Pompeu Fabra. Retrieved from http://www.tdx.cat/handle/10803/52064.

Venkatagiri, H. S., \& Levis, J. M. (2007). Phonological awareness and speech comprehensibility: An exploratory study. Language awareness, 16(4), 263-277. 
Webster, P. E., \& Plante, A. S. (1992). Effects of phonological impairment on word, syllable, and phoneme segmentation and reading. Language, Speech, and Hearing Services in Schools, 23(2), 176-182.

Wei, M. (2006). A literature review on strategies for teaching pronunciation. (ERIC Document Reproduction Service No. ED 491566).

Wells, J. C. (2006). English intonation PB and Audio CD: An introduction. Cambridge: Cambridge University Press.

Wrembel, M. (2005). Metacompetence-oriented model of phonological acquisition: implications for the teaching and learning of second language pronunciation. In Proceedings of the phonetics teaching and learning conference PTLC2005(pp. 1-4).

Wrembel, M. (2011). Metaphonetic awareness in the production of speech. In M. Pawlak, E. WaniekKlimczak \& J. Majer (Eds.), Speaking and instructed foreign language acquisition (pp. 169-182). Clevedon: Multilingual Matters.

Yopp, H.K., \& Yopp, R.H. (2009). Phonological awareness is child's play! Young Children, 64(1), 1221.

Zsiga, E.C. (2013). The sounds of English: An introduction to phonetics and phonology. Oxford: Wiley-Blackwell.

\section{Avrupa ortak ölçüt çerçevesi yöneltimli sesletim incelemesi: Dil öğrencileri ve öğretmenleri için çıkarımlar}

\section{$\ddot{O} \mathbf{z}$}

Eylem yöneltimli bir yaklaşımı benimseyen Avrupa Ortak Ölçüt Çerçevesi (AOÖÇ) (Avrupa Konseyi, 2001), Avrupa'da dil öğrenimi, öğretimi ve değerlendirmesi için genel bir çerçeve olarak düşünülebilir. Yeterlik seviyelerine göre dil becerilerindeki tanımlayıcılarıyla, AOÖÇ (Avrupa Konseyi, 2001) dil öğrenenler, öğretenler ve değerlendirenler tarafindan kılavuz olarak kullanılabilir. Bunu göz önüne alarak, bu makale (i) dil öğrenenler açısından sesbilim ve sesbilgisine özel atıfta bulunarak yetkin bir dil kullanıcısında görülmesi gereken beceri ve yeterlilikleri keşfetmeyi (ii) öğretmen eğitimi bağlamına doğrudan etkileri olan AOÖÇ (Avrupa Konseyi, 2001) ve EFL / ESL Yetişkinler Öğretmeni (TESOL, 2008) standartlarına göre sesletim ve öğretimi ile ilgili olarak öğretmenlik mesleğinin standartlarını betimleyerek AOÖÇ(Avrupa Konseyi, 2001) bakış açısından sesletimi derinlemesine araştırmayı amaçlıyor. Bu makale ayrıca daha fazla tartışma yoluyla önceki araştırmalara atıfta bulunularak önemli sonuçlar doğuracak şekilde sesletim pedagojisi açısından öğretmen eğitimi literatürüne katkıda bulunmayı amaçlamaktadır.

Anahtar sözcükler: öğretmen eğitimi; AOÖÇ; profesyonellik; sesletim; dil yeterliği

\section{AUTHOR BIODATA}

İbrahim Halil Topal is an instructor in the School of Foreign of Languages at Gazi University. He received his BA from the ELT Department of Çukurova University, MA in the same department of Hacettepe University. His research interests are phonetics and phonology, teacher education, educational technology, and culture. 